\title{
Efficacy and Economics of Different Need Based Nitrogen Management Approaches in Winter Rice
}

\author{
Nilufar Akhtar Jahan1, Sabina Yeasmin ${ }^{1}$, Md. Parvez Anwar, ${ }^{1,2}$ Md. Ariful Islam¹, \\ Hamidur Rahman', A. K. M. Mominul Islam1,2 \\ ${ }^{1}$ Department of Agronomy, Bangladesh Agricultural University, Mymensingh, Bangladesh \\ ${ }^{2}$ Weed Management Laboratory, Department of Agronomy, Bangladesh Agricultural University, Mymensingh, Bangladesh \\ Email: *sa binayeasmin@bau.edu.bd
}

How to cite this paper: Jahan, N.A., Yeasmin, S., Anwar, Md.P., Islam, Md.A., Rahman, H. and Islam, A.K.M.M. (2018) Efficacy and Economics of Different Need Based Nitrogen Management Approaches in Winter Rice. American Journal of Plant Sciences, 9, 2601-2611.

https://doi.org/10.4236/ajps.2018.913189

Received: November 23, 2018

Accepted: December 14, 2018

Published: December 17, 2018

Copyright $\odot 2018$ by authors and Scientific Research Publishing Inc. This work is licensed under the Creative Commons Attribution-NonCommercial International License (CC BY-NC 4.0). http://creativecommons.org/licenses/by-nc/4.0/ (c) (i) \&) Open Access

\begin{abstract}
This experiment aimed to study the efficacy of different nitrogen $(\mathrm{N})$ management approaches in winter rice. The experiment consisted of two rice varieties: 1) BRRI (Bangladesh Rice Research Institute) dhan29-an inbred and 2) Dhanigold-a hybrid, and eight $N$ management approaches: 1) BRRI recommended $\mathrm{N}$ (control), 2) Soil analysis based $\mathrm{N}$ management, 3) $\mathrm{N}$ application based on Agro-ecological zone, 4) $20 \mathrm{~kg} \cdot \mathrm{N} \cdot \mathrm{ha}^{-1}$ at $\leq 35 \mathrm{SPAD}$ (Silicon photon activate diode) value, 5) $30 \mathrm{~kg} \cdot \mathrm{N} \cdot \mathrm{ha}^{-1}$ at $\leq 35 \mathrm{SPAD}$ value, 6) 20 $\mathrm{kg} \cdot \mathrm{N} \cdot \mathrm{ha}^{-1}$ at $\leq 3.0 \mathrm{LCC}$ (leaf colour chart) value, 7) $30 \mathrm{~kg} \cdot \mathrm{N} \cdot \mathrm{ha}^{-1}$ at $\leq 3.0 \mathrm{LCC}$ value and 8) Urea Super Granule. Between two varieties, hybrid Dhani gold produced higher grain yield $\left(6.67 \mathrm{t} \cdot \mathrm{ha}^{-1}\right)$ than the inbred BRRI dhan29. Application of $20 \mathrm{~kg} \cdot \mathrm{N} \cdot \mathrm{ha}^{-1}$ at $\leq 3.0 \mathrm{LCC}$ value gave the highest grain yield (7.10 $\left.\mathrm{t} \cdot \mathrm{ha} \mathrm{a}^{-1}\right)$, whereas the lowest grain yield $\left(5.92 \mathrm{t} \cdot \mathrm{ha}^{-1}\right)$ was found from the SPAD approach with $20 \mathrm{~kg} \cdot \mathrm{N} \cdot \mathrm{ha}^{-1}$ at $\leq 35 \mathrm{SPAD}$ value. In case of treatment interaction highest grain yield $\left(7.34 \mathrm{t} \cdot \mathrm{ha}^{-1}\right)$ was found in BRRI dhan 29 coupled with $20 \mathrm{~kg} \cdot \mathrm{N} \cdot \mathrm{ha}^{-1}$ at $\leq 3.0 \mathrm{LCC}$ value with $18 \mathrm{~kg} \cdot \mathrm{N} \cdot$ savings $\mathrm{ha}^{-1}$ over control, maximum gross income $\left(146,800 \mathrm{BDT} \cdot \mathrm{ha}^{-1}\right)$ and net benefit $\left(142,120 \mathrm{BDT} \cdot \mathrm{ha}^{-1}\right)$, which was statistically identical with the grain yield from the interaction of Dhani gold and $30 \mathrm{~kg} \cdot \mathrm{N} \cdot \mathrm{ha}^{-1}$ at $\leq 3.0 \mathrm{LCC}$ value but required 42 $\mathrm{kg} \cdot$ extra $\cdot \mathrm{N} \cdot \mathrm{ha}^{-1}$ (over control). The lowest grain yield $\left(5.19 \mathrm{t} \cdot \mathrm{ha}^{-1}\right.$ ) was found when Dhanigold was coupled with $30 \mathrm{~kg} \cdot \mathrm{N} \cdot \mathrm{ha}^{-1}$ at $\leq 35 \mathrm{SPAD}$ value, while the $20 \mathrm{~kg} \cdot \mathrm{N} \cdot$ application $\cdot \mathrm{ha}^{-1}$ at $\leq 35 \mathrm{SPAD}$ value gave moderate yield $\left(6.87 \mathrm{t} \cdot \mathrm{ha}^{-1}\right)$ with considerable higher gross $\left(139,600 \mathrm{BDT} \cdot \mathrm{ha}^{-1}\right)$ and net $\left(136,090 \mathrm{BDT} \cdot \mathrm{ha}^{-1}\right)$ incomes than the control (gross: 121,000 and net: 115,600 $\left.\mathrm{BDT} \cdot \mathrm{ha}^{-1}\right)$. The results reveal that $20 \mathrm{~kg} \cdot \mathrm{N} \cdot \mathrm{ha}^{-1}$ at $\leq 3.0 \mathrm{LCC}$ value appeared as the promising practice for inbred BRRI dhan 29 , and $30 \mathrm{~kg} \cdot \mathrm{N} \cdot \mathrm{ha}^{-1}$ at $\leq 35$
\end{abstract}


SPAD value for hybrid Dhanigold in terms of yield, $\mathrm{N}$ use efficiency and economic benefit of winter rice.

\section{Keywords}

Rice Nitrogen Demand, Leaf Color Chart, SPAD Meter, Nitrogen Use Efficiency, Nitrogen Economics

\section{Introduction}

Rice (Oryza sativa L.) is the staple food of Bangladesh occupying a very significant position in its agriculture and plays a vital role in the livelihood of her people. Bangladesh is now producing about 32.6 million tons of rough rice to feed her 159.5 million people [1]. Among three rice groups of Bangladesh, winter rice (locally known as "boro rice") covers 6.74 million hectares, which is $54.97 \%$ of total rice area with production of 14.89 million tons [2]. The increased rice production in last few decades has been possible largely due to the adoption of modern rice varieties on around $66 \%$ of the rice land, which contributes to about $73 \%$ of the country's total rice production [3]. Due to high population pressure, horizontal expansion of land is not possible. Therefore, increasing yield per unit area is the only means to meet food demand of the nation. Among the various factors responsible for increasing yield along with its quality, fertilizer management (especially nitrogenous fertilizer) is of paramount importance.

Under Bangladesh context, rice plants respond significantly to the application of nitrogenous fertilizers, since the soil all over the country lacks sufficient amount of nitrogen $(\mathrm{N})$ due to low organic matter content and insufficient replenishment of $\mathrm{N}$ losses as well. In Bangladesh, the most commonly practiced method of applying nitrogenous fertilizer in rice is a basal application of prilled urea before transplanting followed by one or two top-dressings in the floodwater within 3 - 5 weeks after transplanting. Many studies found these practices inefficient since generally only about one-third of the applied $\mathrm{N}$ fertilizer through this method is used by plants and most of it goes under severe losses when applied as inorganic source in puddled field [4]. The consequence of high $\mathrm{N}$ application is high pesticide use to control pests, more expenditure on pesticides, and reduced yield and poor grain quality due to lodging [5]. It is, therefore, essential to find out the suitable rate of $\mathrm{N}$ fertilizer with proper method of application and source for efficient utilization of this element by the crop plants for better yield performance and higher profitability.

According to Bangladesh Rice Research Institute (BRRI) recommendation, fixed rate of nitrogenous fertilizer is applied at certain times for a particular rice variety growing in a large area. This approach has served its purpose in producing good yields, but it is limited in its capacity to increase nutrient use efficiency. Deep placement of Urea Super Granules (USG) at $10 \mathrm{~cm}$ depth is another way to reduce $\mathrm{N}$ loss by increasing its efficiency for better grain production [6]. Gener- 
ally, each soil has its inherent nutrient supplying capacity. Thus, soil analysis can be an effective means for location specific and yield goal basis fertilizer recommendation. However, soil test based recommendations remain ignorant about the dynamics of nutrient release from crop residues, organic manures and irrigation water, and hence has not been found very successful in rice. Moreover, the fertility status of soils of different Agro-Ecological Zones (AEZ) of Bangladesh differs from each other. Thus, AEZ based nutrient management is another technique especially for efficient $\mathrm{N}$ management although this method does not take into account the high field-to-field variability.

Rice plant requires different amounts of nutrients in different fields, depending on native nutrient supply and crop demand. Excess nutrient application compared to the crop requirement may cause toxicity whereas lower amounts may cause nutrient mining. To increase nutrient use efficiency, the only mantra is to congruence of $\mathrm{N}$ supply and crop demand. This is possible with the chlorophyll meter (Silicon photon activate diode or SPAD) and leaf colour chart (LCC) techniques. The SPAD meter is a tool that enables to determine the relative amount of chlorophyll content by measuring leaf greenness [7]. Since chlorophyll content is strongly related to $\mathrm{N}$ concentration, SPAD meters can be used as the indicator of need based $\mathrm{N}$ application [8] [9]. On the other hand, LCC is an inexpensive and simple tool for monitoring the relative greenness of a rice leaf as an indicator of the leaf $\mathrm{N}$ status [10] [11]. It allows farmers to understand whether or not urea is needed by the crop at any point of rice growing, thus helps in improving decisions on both timing and quantity of urea application. Thus, LCC based $\mathrm{N}$ management can increase the mean grain yield, ensures vigorous growth of crop plants and also reduces the loss of nitrogenous fertilizers [5].

However, under the present context of very low use efficiency of urea fertilizer in Bangladesh, it is very important to find out the appropriate form and method of nitrogenous fertilizer application for improving the yield of puddled transplanted winter rice. Hence, current research was undertaken to compare the performance of different $\mathrm{N}$ management approaches in terms of productivity of hybrid and inbred winter rice varieties, and to find out the most efficient and cost-effective $\mathrm{N}$ management approach for increasing grain yield of winter rice.

\section{Materials and Methods}

\subsection{Experimental Site and Soil}

The experiment was carried out at the Agronomy Field Laboratory $\left(90^{\circ} 25^{\prime} 35.2^{\prime \prime} \mathrm{E}\right.$ and $24^{\circ} 43^{\prime} 07.3^{\prime \prime N}$ ), Bangladesh Agricultural University, Mymensingh, Bangladesh during December 2016 to May 2017. The experimental site belongs to the Old Brahmaputra Floodplain Agro-ecological zone (AEZ-9). The land was medium high and the soil was non-calcareous dark-grey, silty-loam textured slightly acidic to neutral ( $\mathrm{pH}$ 6.82), medium fertile and low in nitrogen $(\mathrm{N})$ content $(0.1 \%)$ 


\subsection{Experimental Treatments and Design}

The experiment was laid out in a randomized complete block design with three replications consisting of two rice varieties; 1) BRRI dhan29-an inbred and 2) Dhani gold-a hybrid; and eight $\mathrm{N}$ management approaches; 1) BRRI recommended N, 2) Soil analysis based $\mathrm{N}$ management, 3) $\mathrm{N}$ application based on Agro-ecological zone (AEZ), 4) $20 \mathrm{~kg} \cdot \mathrm{N} \cdot \mathrm{ha}^{-1}$ at $\leq 35 \mathrm{SPAD}$ value, 5) $30 \mathrm{~kg} \cdot \mathrm{N} \cdot \mathrm{ha}^{-1}$ at $\leq 35 \mathrm{SPAD}$ value, 6) $20 \mathrm{~kg} \cdot \mathrm{N} \cdot \mathrm{ha}^{-1}$ at $\leq 3.0 \mathrm{LCC}$ value, 7) $30 \mathrm{~kg} \cdot \mathrm{N} \cdot \mathrm{ha}^{-1}$ at $\leq 3.0$ LCC value and 8) Urea Super Granule (USG). The size of the unit plot was $5 \mathrm{~m}^{2}$ $(2.5 \mathrm{~m} \times 2 \mathrm{~m})$ and the spaces between blocks and plots were $1 \mathrm{~m}$ and $0.5 \mathrm{~m}$, respectively.

\subsection{Crop Husbandry}

Forty days old seedlings were transplanted in the puddled field using two seedlings hill ${ }^{-1}$ on 5 January 2017. Triple super phosphate, muriate of potash, gypsum and zinc sulphate at the rate of $98,165,113$ and $12 \mathrm{~kg} \cdot \mathrm{ha}^{-1}$, respectively were applied as basal one day before transplanting. Nitrogenous fertilizer-urea was applied as per treatment specification. For the BRRI recommended $\mathrm{N}$ approach, prilled urea was applied in three equal splits at the rate of $300 \mathrm{~kg} \cdot \mathrm{ha}^{-1}$ at 15,35 and 65 days after transplanting (DAT). For the soil analysis based $\mathrm{N}$ management, prilled urea at the rate of $313 \mathrm{~kg} \cdot \mathrm{ha}^{-1}$ (according to the soil test value) was applied at 15, 35 and $65 \mathrm{DAT}$. For the AEZ based $\mathrm{N}$ application approach, about $326 \mathrm{~kg} \cdot$ prilled.urea $\cdot \mathrm{ha}^{-1}$ was applied by following the splits mentioned before. For the SPAD and LCC treatments, prilled urea was applied when needed according to the treatments criteria. The SPAD and LCC readings were taken from the middle portion of the fully expanded leaves from 5 randomly selected hills from 20 DAT to heading at 10 day intervals. When the SPAD reading was down to critical value 35 and LCC value to 3.0, then the respective treatment plots were fertilized with allocated amount of urea. The pellets of USG as per treatment specification were placed at $3-4$ inch depth at 15 DAT in the center of four hills in alternate rows. Intercultural operations were done as and when necessary. Flood irrigation was applied to maintain a constant level of standing water up to $6 \mathrm{~cm}$ in early stage to enhance tillering and $10-12 \mathrm{~cm}$ in later stage to discourage late tillering. The field was finally drained out 15 days before harvest to enhance maturity. Plants were infested with rice stem borer and rice bug which were successfully controlled by applying Furadan @ $10 \mathrm{~kg} \cdot \mathrm{ha}^{-1}$.

\subsection{Data Collection}

Five hills (excluding border hills) were randomly selected from each unit plot prior to harvest for recording data on different yield components and yield of rice. The date of harvesting was determined when $90 \%$ of the grains became golden yellow in color. An area of central $1 \mathrm{~m}^{2}$ was harvested in each plot to record the yields of grain and straw. The harvested crop was then threshed, cleaned and dried to a moisture content of $14 \%$. Weight of grain and straw were 
recorded and converted into tha ${ }^{-1}$.

\subsection{Statistical Analysis}

Data obtained were analyzed by MSTAT-Cstatistical computer package program using the "Analysis of variance" technique at $5 \%$ level of significance and mean differences was adjudged by Duncan's Multiple Range Test (DMRT) [12].

\section{Results and Discussion}

\subsection{Effect of Variety and N Management Approaches on Rice Productivity}

Variety, $\mathrm{N}$ management approaches and their interactions had significant influence on most of the yield contributing characters except panicle length and yield of winter rice (Table 1 and Table 2). However, varietal effect was insignificant on harvest index, and N management approaches on 1000-grain weight. Hybrid Dhani gold produced higher number of effective tillers.hill ${ }^{-1}$ (10.97), grains panicle $^{-1}$ (91.46), grain $\left(6.67 \mathrm{t} \cdot \mathrm{ha}^{-1}\right)$ and straw yield $\left(8.79 \mathrm{t} \cdot \mathrm{ha}^{-1}\right)$ than BRRI dhan29 (Table 1). The variation between the varieties in terms of yield and yield components might occurred due to the differences in their genetic potentiality [13] [14] [15].

Application of $20 \mathrm{~kg} \cdot \mathrm{N} \cdot \mathrm{ha}^{-1}$ at $\leq 3.0 \mathrm{LCC}$ value produced the highest number of effective tillers hill ${ }^{-1}$ (11.67) (Table 1) which resulted inthe highest grain yield $\left(7.10 \mathrm{t} \cdot \mathrm{ha}^{-1}\right)$ as well as straw yield $\left(9.10 \mathrm{t} \cdot \mathrm{ha}^{-1}\right)$ and biological yield $\left(16.21 \mathrm{t} \cdot \mathrm{ha}^{-1}\right)$ (Table 1). Use of urea super granule (USG) produced the highest number of grains panicle $^{-1}$ (93.99) with lowest number of non-effective tillers hill ${ }^{-1}$ (1.93). The highest harvest index (44.64\%) was found under soil analysis based $\mathrm{N}$ management. Application of $20 \mathrm{~kg} \cdot \mathrm{N} \cdot \mathrm{ha}^{-1}$ at $\leq 35 \mathrm{SPAD}$ value gave the lowest number of effective tillers hill ${ }^{-1}$ (10.07), grain yield $\left(5.92 \mathrm{t} \cdot \mathrm{ha}^{-1}\right)$ and harvest index (41.37\%), whereas BRRI recommended $\mathrm{N}$ management gave the lowest grains panicle $^{-1}$ (88.89) and straw yield $\left(8.02 \mathrm{t} \cdot \mathrm{ha}^{-1}\right)$. In case of $30 \mathrm{~kg} \cdot \mathrm{N} \cdot \mathrm{ha}^{-1}$ at $\leq 35$ SPAD value, the grain yield $\left(6.75 \mathrm{t} \cdot \mathrm{ha}^{-1}\right)$ was significantly higher than the 20 $\mathrm{kg} \cdot \mathrm{N} \cdot \mathrm{ha}^{-1}$ at $\leq 35 \mathrm{SPAD}$ value (Table 1 ). Similar results were also reported by [11] [16] [17] [18]. For SPAD treatments, application of $20 \mathrm{~kg} \cdot \mathrm{N} \cdot \mathrm{ha} \mathrm{h}^{-1} \mathrm{might}$ did not meet the requirement of the plant properly or might not have efficiently used the applied $\mathrm{N}$ which resulted lowest grain yield.

Considering the interaction between variety and $\mathrm{N}$ management approach, the highest grain yield $\left(7.34 \mathrm{t} \cdot \mathrm{ha}^{-1}\right)$ was observed when BRRI dhan29 was fertilized with $20 \mathrm{~kg} \cdot \mathrm{N} \cdot \mathrm{ha}^{-1}$ at $\leq 3.0 \mathrm{LCC}$ value (Table 2). While, the highest grain yield $\left(7.25 \mathrm{t} \cdot \mathrm{ha}^{-1}\right)$, number of effective tillers hill ${ }^{-1}(12.60)$ and straw yield $(9.42$ $\mathrm{t} \cdot \mathrm{ha}^{-1}$ ) in Dhani gold were obtained from $30 \mathrm{~kg} \cdot \mathrm{N} \cdot \mathrm{ha}^{-1}$ at $\leq 3 \mathrm{LCC}$ value (Table 2). On the other hand, Dhani gold applied with USG gave the highest number of grains panicle ${ }^{-1}$ (94.93) and harvest index (45.26\%). Similar result was also obtained when soil analysis based $\mathrm{N}$ management was practiced in Dhani gold. The lowest grain yield (5.19 $\mathrm{t} \cdot \mathrm{ha}^{-1}$ ) and harvest index (38.69\%) were found from the 
Table 1. Effect of variety and nitrogen $(\mathrm{N})$ management approaches on yield components and yield of winter rice.

\begin{tabular}{|c|c|c|c|c|c|c|c|}
\hline Treatment & $\begin{array}{c}\text { No. of } \\
\text { effective } \\
\text { tillers hill }{ }^{-1}\end{array}$ & $\begin{array}{c}\text { Panicle } \\
\text { length }(\mathrm{cm})\end{array}$ & $\begin{array}{c}\text { No. of grains } \\
\text { panicle }^{-1}\end{array}$ & $\begin{array}{l}1000 \text { grain } \\
\text { weight }(\mathrm{g})\end{array}$ & $\begin{array}{l}\text { Grain yield } \\
\left(\mathrm{t} \cdot \mathrm{ha}^{-1}\right)\end{array}$ & $\begin{array}{l}\text { Straw yield } \\
\left(\mathrm{t} \cdot \mathrm{ha}^{-1}\right)\end{array}$ & $\begin{array}{c}\text { Harvest } \\
\text { index (\%) }\end{array}$ \\
\hline \multicolumn{8}{|l|}{ Variety } \\
\hline BRRI dhan29 & $10.71 b$ & 21.61 & $89.93 b$ & $23.58 \mathrm{a}$ & $6.61 b$ & $8.53 b$ & 43.67 \\
\hline Dhani gold & $10.97 \mathrm{a}$ & 21.66 & $91.46 \mathrm{a}$ & $22.83 b$ & $6.67 \mathrm{a}$ & $8.79 \mathrm{a}$ & 43.07 \\
\hline Standard error & 0.086 & 0.050 & 0.465 & 0.198 & 0.020 & 0.073 & 0.316 \\
\hline Level of significance & * & NS & * & $* *$ & * & $* *$ & NS \\
\hline \multicolumn{8}{|l|}{$\mathrm{N}$ management approaches } \\
\hline BRRI recommended $\mathrm{N}$ & $10.43 \mathrm{c}$ & 21.40 & $88.89 b$ & 23.77 & $6.27 \mathrm{f}$ & $8.02 \mathrm{c}$ & $43.85 \mathrm{a}$ \\
\hline Soil analysis based $\mathrm{N}$ management & $11.30 \mathrm{ab}$ & 21.58 & $90.93 b$ & 22.15 & $6.85 c$ & $8.50 \mathrm{~b}$ & $44.64 a$ \\
\hline $\mathrm{N}$ management based on agro-ecological zone & $11.07 \mathrm{~b}$ & 21.59 & $90.22 b$ & 23.50 & $6.67 \mathrm{de}$ & $8.77 \mathrm{ab}$ & $43.18 \mathrm{ab}$ \\
\hline $20 \mathrm{~kg} \cdot \mathrm{N} \cdot \mathrm{ha}^{-1}$ at $\leq 35 \mathrm{SPAD}$ value & $10.07 \mathrm{c}$ & 21.91 & $90.96 \mathrm{~b}$ & 23.67 & $5.92 \mathrm{~g}$ & $8.34 \mathrm{bc}$ & $41.37 \mathrm{~b}$ \\
\hline $30 \mathrm{~kg} \cdot \mathrm{N} \cdot \mathrm{ha}^{-1}$ at $\leq 35 \mathrm{SPAD}$ value & $10.37 \mathrm{c}$ & 21.53 & $89.80 \mathrm{~b}$ & 23.15 & $6.75 \mathrm{~cd}$ & $8.65 \mathrm{ab}$ & $43.84 \mathrm{a}$ \\
\hline $20 \mathrm{~kg} \cdot \mathrm{N} \cdot \mathrm{ha}^{-1}$ at $\leq 3.0 \mathrm{LCC}$ value & $11.67 \mathrm{a}$ & 21.68 & $89.67 \mathrm{~b}$ & 23.43 & $7.10 \mathrm{a}$ & $9.10 \mathrm{a}$ & $43.83 \mathrm{a}$ \\
\hline $30 \mathrm{~kg} \cdot \mathrm{N} \cdot \mathrm{ha}^{-1}$ at $\leq 3.0 \mathrm{LCC}$ value & $11.33 \mathrm{ab}$ & 21.72 & $91.13 b$ & 23.08 & $6.98 b$ & $9.08 \mathrm{a}$ & $43.48 \mathrm{a}$ \\
\hline Urea super granule (USG) & $10.47 \mathrm{c}$ & 21.65 & $93.99 a$ & 22.87 & $6.56 \mathrm{e}$ & 8.79ab & $42.77 \mathrm{ab}$ \\
\hline Standard error & 0.171 & 0.101 & 0.929 & 0.396 & 0.039 & 0.145 & 0.633 \\
\hline Level of significance & $* *$ & NS & * & NS & $* *$ & $* *$ & * \\
\hline CV (\%) & 3.86 & 1.14 & 2.51 & 4.19 & 1.44 & 4.12 & 3.57 \\
\hline
\end{tabular}

In a column, figures with the same letter(s) or without letter do not differ significantly whereas figures with dissimilar letter differ significantly (as per DMRT $) . C V=$ coefficient of variation, ${ }^{*}=$ Significant at probability level $(p) 0.05,{ }^{* *}=$ Significant at $p 0.01, \mathrm{NS}=$ Non-significant. BRRI $=$ Bangladesh rice research institute, $\mathrm{SPAD}=$ Silicon photon activate diode and LCC $=$ Leaf colour chart.

application of $20 \mathrm{~kg} \cdot \mathrm{N} \cdot \mathrm{ha}^{-1}$ at $\leq 35 \mathrm{SPAD}$ value in Dhani gold, whereas the 30 $\mathrm{kg} \cdot \mathrm{N} \cdot \mathrm{ha}^{-1}$ at $\leq 35 \mathrm{SPAD}$ value approach gave the second highest grain yield (6.98 $\left.\mathrm{t} \cdot \mathrm{ha}^{-1}\right)$ of the same variety. Due to the interaction between variety and $\mathrm{N}$ management approaches both the varieties might have responded diversely to the $\mathrm{N}$ applied through different $\mathrm{N}$ management approaches resulted in wide variation in yield contributing parameters and yield [19] [20].

\subsection{Efficiency and Economics of Nitrogen Use}

Among different $\mathrm{N}$ management approaches studied in the experiment, few showed considerable better performance in respect of efficient $\mathrm{N}$ management and yield maximization compared to the existing BRRI recommended varietal $\mathrm{N}$ management approach (control) in winter rice (Table 3). Total amount of $\mathrm{N}$ applied for different management approaches ranged from 60 to $180 \mathrm{~kg} \cdot \mathrm{ha}^{-1}$. Soil analysis and AEZ based $\mathrm{N}$ managements required 6\%-12\% extra $\mathrm{N}$ application compared to the control but did not always increase the yield (decrease of 3.08\% to increase of 17\%) particularly for BRRI dhan29 (Table 3). Application of 20 $\mathrm{kg} \cdot \mathrm{N} \cdot \mathrm{ha}^{-1}$ at $\leq 35 \mathrm{SPAD}$ value required the least amount of $\mathrm{N} \cdot \mathrm{ha}^{-1}(60 \mathrm{~kg})$ with 
Table 2. Effect of interaction between variety and Nitrogen $(\mathrm{N})$ management approaches on yield components and yield of winter rice.

\begin{tabular}{|c|c|c|c|c|c|c|c|c|}
\hline Variety & $\mathrm{N}$-management approaches & $\begin{array}{l}\text { No. of effective } \\
\text { tillers hill }\end{array}$ & $\begin{array}{c}\text { Panicle } \\
\text { length }(\mathrm{cm})\end{array}$ & $\begin{array}{c}\text { No. of } \\
\text { grains } \\
\text { panicle }^{-1}\end{array}$ & $\begin{array}{l}1000 \text { grain } \\
\text { weight }(\mathrm{g})\end{array}$ & $\begin{array}{l}\text { Grain } \\
\text { yield } \\
\left(\mathrm{t} \cdot \mathrm{ha}^{-1}\right)\end{array}$ & $\begin{array}{l}\text { Straw yield } \\
\quad\left(\mathrm{t} \cdot \mathrm{ha}^{-1}\right)\end{array}$ & $\begin{array}{c}\text { Harvest } \\
\text { index } \\
(\%)\end{array}$ \\
\hline \multirow{8}{*}{$\begin{array}{c}\text { BRRI } \\
\text { dhan29 }\end{array}$} & BRRI recommended $\mathrm{N}$ (control) & $11.07 \mathrm{~cd}$ & $21.5 \mathrm{a}-\mathrm{d}$ & $89.46 \mathrm{bcd}$ & $24.07 \mathrm{abc}$ & $6.49 \mathrm{~g}$ & $8.10 \mathrm{ef}$ & $44.50 \mathrm{a}$ \\
\hline & Soil analysis based $\mathrm{N}$ management & $10.67 c-f$ & $21.42 \mathrm{bcd}$ & $92.90 \mathrm{ab}$ & $22.44 c-f$ & $6.63 \mathrm{fg}$ & $8.44 \mathrm{c}-\mathrm{f}$ & $44.02 \mathrm{a}$ \\
\hline & $\begin{array}{l}\mathrm{N} \text { management based on } \\
\text { agro-ecological zone }\end{array}$ & $11.00 \mathrm{cde}$ & $21.34 \mathrm{~cd}$ & $88.01 \mathrm{~cd}$ & $22.47 \mathrm{c}-\mathrm{f}$ & $6.29 \mathrm{~h}$ & $8.52 \mathrm{c}-\mathrm{f}$ & $42.49 \mathrm{a}$ \\
\hline & $20 \mathrm{~kg} \cdot \mathrm{N} \cdot \mathrm{ha}^{-1}$ at $\leq 35 \mathrm{SPAD}$ value & $10.00 \mathrm{fg}$ & $21.89 \mathrm{ab}$ & $89.88 \mathrm{bcd}$ & $23.87 \mathrm{abc}$ & $6.65 f g$ & $8.45 c-f$ & $44.05 \mathrm{a}$ \\
\hline & $30 \mathrm{~kg} \cdot \mathrm{N} \cdot \mathrm{ha}^{-1}$ at $\leq 35 \mathrm{SPAD}$ value & $10.27 \mathrm{efg}$ & $21.46 \mathrm{a}-\mathrm{d}$ & $88.35 \mathrm{~cd}$ & $25.07 \mathrm{a}$ & $6.53 \mathrm{~g}$ & $8.40 \mathrm{c}-\mathrm{f}$ & $43.72 \mathrm{a}$ \\
\hline & $20 \mathrm{~kg} \cdot \mathrm{N} \cdot \mathrm{ha}^{-1}$ at $\leq 3.0 \mathrm{LCC}$ value & $11.93 \mathrm{ab}$ & $21.85 \mathrm{ab}$ & $90.37 \mathrm{bcd}$ & $23.00 \mathrm{~b}-\mathrm{e}$ & $7.34 \mathrm{a}$ & $9.35 \mathrm{ab}$ & $43.98 \mathrm{a}$ \\
\hline & $30 \mathrm{~kg} \cdot \mathrm{N} \cdot \mathrm{ha}^{-1}$ at $\leq 3.0 \mathrm{LCC}$ value & $10.07 \mathrm{fg}$ & $21.60 a-d$ & $87.46 \mathrm{~d}$ & $25.05 \mathrm{a}$ & $6.72 \mathrm{ef}$ & $8.74 \mathrm{~b}-\mathrm{e}$ & $43.47 \mathrm{a}$ \\
\hline & Urea super granule (USG) & $10.67 c-f$ & $21.82 \mathrm{abc}$ & $93.05 \mathrm{ab}$ & $22.67 b-f$ & $6.24 \mathrm{~h}$ & $8.22 \mathrm{def}$ & $43.16 \mathrm{a}$ \\
\hline \multirow{8}{*}{ Dhanigold } & BRRI recommended N (control) & $9.800 \mathrm{~g}$ & $21.31 \mathrm{~d}$ & $88.32 \mathrm{~cd}$ & $23.47 a-d$ & $6.05 \mathrm{i}$ & $7.95 f$ & $43.21 \mathrm{a}$ \\
\hline & Soil analysis based $\mathrm{N}$ management & $11.93 \mathrm{ab}$ & $21.74 a-d$ & $88.95 \mathrm{bcd}$ & $21.87 \mathrm{def}$ & $7.08 \mathrm{~b}$ & $8.56 \mathrm{c}-\mathrm{f}$ & $45.26 \mathrm{a}$ \\
\hline & $\begin{array}{l}\mathrm{N} \text { management based on } \\
\text { agro-ecological zone }\end{array}$ & $11.13 \mathrm{~cd}$ & $21.85 \mathrm{ab}$ & $92.44 \mathrm{abc}$ & $24.53 \mathrm{ab}$ & $7.05 \mathrm{bc}$ & $9.02 \mathrm{a}-\mathrm{c}$ & $43.87 \mathrm{a}$ \\
\hline & $20 \mathrm{~kg} \cdot \mathrm{N} \cdot \mathrm{ha}^{-1}$ at $\leq 35 \mathrm{SPAD}$ value & $10.13 \mathrm{fg}$ & $21.93 \mathrm{a}$ & $92.04 \mathrm{abc}$ & $23.47 a-d$ & $5.19 \mathrm{j}$ & $8.23 \mathrm{~d}-\mathrm{f}$ & $38.69 b$ \\
\hline & $30 \mathrm{~kg} \cdot \mathrm{N} \cdot \mathrm{ha}^{-1}$ at $\leq 35 \mathrm{SPAD}$ value & $10.47 \mathrm{~d}-\mathrm{g}$ & $21.60 a-d$ & $91.25 \mathrm{a}-\mathrm{d}$ & $21.24 \mathrm{ef}$ & $6.98 b-d$ & $8.90 \mathrm{a}-\mathrm{d}$ & $43.96 a$ \\
\hline & $20 \mathrm{~kg} \cdot \mathrm{N} \cdot \mathrm{ha}^{-1}$ at $\leq 3.0 \mathrm{LCC}$ value & $11.40 \mathrm{bc}$ & $21.51 \mathrm{a}-\mathrm{d}$ & $88.97 \mathrm{bcd}$ & $23.87 \mathrm{abc}$ & $6.87 \mathrm{de}$ & $8.86 a-d$ & $43.69 \mathrm{a}$ \\
\hline & $30 \mathrm{~kg} \cdot \mathrm{N} \cdot \mathrm{ha}^{-1}$ at $\leq 3.0 \mathrm{LCC}$ value & $12.60 \mathrm{a}$ & $21.84 \mathrm{ab}$ & $94.80 \mathrm{a}$ & $21.11 \mathrm{f}$ & $7.25 \mathrm{a}$ & $9.42 \mathrm{a}$ & $43.49 \mathrm{a}$ \\
\hline & Urea super granule (USG) & $10.27 \mathrm{efg}$ & $21.48 \mathrm{a}-\mathrm{d}$ & $94.93 a$ & $23.07 b-e$ & $6.89 \mathrm{~cd}$ & $9.37 \mathrm{ab}$ & $42.39 a$ \\
\hline \multicolumn{2}{|c|}{ Standard error } & 0.242 & 0.143 & 1.31 & 0.561 & 0.055 & 0.206 & 0.894 \\
\hline \multicolumn{2}{|c|}{ Level of significance } & $* *$ & * & $* *$ & ** & ** & $* *$ & * \\
\hline \multicolumn{2}{|l|}{ CV (\%) } & 3.86 & 1.14 & 2.51 & 4.19 & 1.44 & 4.12 & 3.57 \\
\hline
\end{tabular}

In a column, figures with the same letter(s) or without letter do not differ significantly whereas figures with dissimilar letter differ significantly (as per DMRT). $\mathrm{CV}=$ coefficient of variation, ${ }^{*}=$ Significant at probability level $(p) 0.05,{ }^{*}=$ Significant at $p 0.01, \mathrm{NS}=$ Non-significant. BRRI $=$ Bangladesh rice research institute, $\mathrm{SPAD}=$ Silicon photon activate diode and LCC $=$ Leaf colour chart.

maximum saving $\left(78 \mathrm{~kg} \cdot \mathrm{ha}^{-1}\right)$ in terms of required amount of $\mathrm{N}$ over control and maximum partial factor productivity for $\mathrm{N}$ in BRRI dhan29 (110.83 kg rice grain $\left.\mathrm{kg}^{-1} \cdot \mathrm{N}\right)$ followed by Dhani gold $\left(86.5 \mathrm{~kg}\right.$ rice grain $\left.\mathrm{kg}^{-1} \cdot \mathrm{N}\right)$. However, with this SPAD approach, the grain yield was $6.65 \mathrm{t} \cdot \mathrm{ha}^{-1}$ in BRRI dhan29 and $5.19 \mathrm{t} \cdot \mathrm{ha}^{-1}$ in Dhani Gold which was an increase of yield by $2.47 \%$ and decrease by $14.21 \%$ for the respective variety over control. With $30 \mathrm{~kg} \cdot \mathrm{N} \cdot \mathrm{ha}^{-1}$ application at $\leq 35 \mathrm{SPAD}$, grain yield was moderate $\left(6.53-6.98 \mathrm{t} \cdot \mathrm{ha}^{-1}\right)$ for both varieties with $48 \% \mathrm{~N}$ saving over control, and moderate partial factor productivity for N. Application of 30 $\mathrm{kg} \cdot \mathrm{N} \cdot \mathrm{ha}^{-1}$ at $\leq 3.0 \mathrm{LCC}$ value required the highest amount of $\mathrm{N} \cdot \mathrm{ha}^{-1}(180 \mathrm{~kg})$ but also had the lowest partial factor productivity for $\mathrm{N}$ (37.33 and $40.27 \mathrm{~kg}$ rice grain $\mathrm{kg}^{-1} \cdot \mathrm{N}$ for BRRI dhan29 and Dhani gold, respectively) and did not gave the highest grain yield for BRRI dhan29. Among all the treatments, the highest amount of grain yield $\left(7.34 \mathrm{t} \cdot \mathrm{ha}^{-1}\right)$ was found from BRRI dhan29 with 20 $\mathrm{kg} \cdot \mathrm{N} \cdot \mathrm{ha}^{-1}$ at $\leq 3.0$ LCC value which was the maximum (13.1\%) yield increment 
Table 3. Comparative performances of different nitrogen $(\mathrm{N})$ management approaches in terms of $\mathrm{N}$ saving and yield improvement in winter rice.

\begin{tabular}{|c|c|c|c|c|c|c|c|c|}
\hline \multirow[t]{2}{*}{$\mathrm{N}$ management approaches } & \multirow{2}{*}{$\begin{array}{c}\text { Total } \\
\text { amount of } \mathrm{N} \\
\text { added } \\
\left(\mathrm{kg} \cdot \mathrm{ha}^{-1}\right)\end{array}$} & \multirow{2}{*}{$\begin{array}{c}\text { Amount of N } \\
\text { saved }(-) / \text { extra } \\
\text { added }(+) \\
\text { compared to } \\
\text { control }\left(\mathrm{kg} \cdot \mathrm{ha}^{-1}\right)\end{array}$} & \multicolumn{2}{|c|}{$\begin{array}{l}\text { Rice grain yield } \\
\qquad\left(\mathrm{t} \mathrm{ha}^{-1}\right)\end{array}$} & \multicolumn{2}{|c|}{$\begin{array}{l}\text { \%Yield increased } \\
(+) / \text { decreased }(-) \\
\text { over control }\end{array}$} & \multicolumn{2}{|c|}{$\begin{array}{l}\text { Partial factor } \\
\text { productivity } \\
\quad \text { for } \mathrm{N} \\
\left(\mathrm{kg} \cdot \text { grain } \cdot \mathrm{kg}^{-1} \cdot \mathrm{N}\right)\end{array}$} \\
\hline & & & $\begin{array}{c}\text { BRRI } \\
\text { dhan29 }\end{array}$ & $\begin{array}{l}\text { Dhani } \\
\text { gold }\end{array}$ & $\begin{array}{l}\text { BRRI } \\
\text { dhan29 }\end{array}$ & $\begin{array}{l}\text { Dhani } \\
\text { gold }\end{array}$ & $\begin{array}{c}\text { BRRI } \\
\text { dhan29 }\end{array}$ & $\begin{array}{c}\text { Dhani } \\
\text { gold }\end{array}$ \\
\hline BRRI recommended $\mathrm{N}$ (control) & 138 & 0 & 6.49 & 6.05 & 0 & 0 & 47.0 & 43.8 \\
\hline Soil analysis based $\mathrm{N}$ management & 144 & +6 & 6.63 & 7.08 & +2.16 & +17.02 & 46.0 & 49.2 \\
\hline $\begin{array}{l}\mathrm{N} \text { management based on } \\
\text { agro-ecological zone }\end{array}$ & 150 & +12 & 6.29 & 7.05 & -3.08 & +16.53 & 41.9 & 47.0 \\
\hline $20 \mathrm{~kg} \cdot \mathrm{N} \cdot \mathrm{ha}^{-1}$ at $\leq 35 \mathrm{SPAD}$ value & 60 & -78 & 6.65 & 5.19 & +2.47 & -14.21 & 110.8 & 86.5 \\
\hline $30 \mathrm{~kg} \cdot \mathrm{N} \cdot \mathrm{ha}^{-1}$ at $\leq 35 \mathrm{SPAD}$ value & 90 & -48 & 6.53 & 6.98 & +0.62 & +15.37 & 72.6 & 77.6 \\
\hline $20 \mathrm{~kg} \cdot \mathrm{N} \cdot \mathrm{ha}^{-1}$ at $\leq 3.0 \mathrm{LCC}$ value & 120 & -18 & 7.34 & 6.87 & +13.1 & +13.55 & 61.2 & 57.3 \\
\hline $30 \mathrm{~kg} \cdot \mathrm{N} \cdot \mathrm{ha}^{-1}$ at $\leq 3.0 \mathrm{LCC}$ value & 180 & +42 & 6.72 & 7.25 & +3.54 & +19.83 & 37.3 & 40.3 \\
\hline Urea super granule (USG) & 80 & -58 & 6.24 & 6.89 & -3.85 & +13.88 & 78.0 & 86.1 \\
\hline
\end{tabular}

BRRI $=$ Bangladesh Rice Research Institute, SPAD $=$ Silicon photon activate diode and LCC $=$ Leaf colour chart. For N, $+=\mathrm{N}$ extra added compared to control, and - = N saved compared to control; For yield, $+=$ yield increased over control, and $-=$ yield decreased over control; For a treatment, saved /extra added $\mathrm{N}$ compared to control $\left(\mathrm{kg} \cdot \mathrm{ha}^{-1}\right)=\mathrm{N}$ applied in control $\left(\mathrm{kg} \cdot \mathrm{ha}{ }^{-1}\right)$-applied in the treatment $\left(\mathrm{kg} \cdot \mathrm{ha}^{-1}\right)$. For a treatment, yield increased/decreased over control $(\%)=\frac{\text { Yield in control }- \text { Yield of the treatment }}{\text { Yield in control }} \times 100$. Partial factor productivity for $\mathrm{N}\left(\mathrm{kg} \cdot\right.$ grain $\left.\cdot \mathrm{kg}^{-1} \cdot \mathrm{N}\right)=\frac{\text { Grain yield }(\mathrm{kg})}{\operatorname{Applied~} \mathrm{N}(\mathrm{kg})}$.

among $\mathrm{N}$ management approaches over control for the same variety. Additionally, this approach saved considerable amount of $\mathrm{N}\left(18 \mathrm{~kg} \cdot \mathrm{ha}^{-1}\right)$ compared to control also with notable partial factor productivity for $\mathrm{N}\left(61.16 \mathrm{~kg} \cdot\right.$.rice.grain $\left.\cdot \mathrm{kg}^{-1} \cdot \mathrm{N}\right)$ (Table 3). With USG application about $58 \% \mathrm{~N}$ was saved but the grain yield wad decreased by $3.85 \%$ for BRRI dhan 29 and increased by $13.88 \%$ for Dhani gold over control.

The cost for required amount of nitrogenous fertilizer (urea) ha $\mathrm{ha}^{-1}$ ranged from 2340 (for $20 \mathrm{~kg} \cdot \mathrm{N} \cdot \mathrm{ha}^{-1}$ at $\leq 35 \mathrm{SPAD}$ value) to $7038 \mathrm{BDT}$ (for $30 \mathrm{~kg} \cdot \mathrm{N} \cdot \mathrm{ha}^{-1}$ at $\leq 3.0$ LCC value) depending on the treatments (Table 4). With the lowest $\mathrm{N}$ cost investment, both the gross income $\left(130,600 \mathrm{BDT} \cdot \mathrm{ha}^{-1}\right.$ and 139,600 BDT.ha ${ }^{-1}$ for BRRI dhan29 and Dhani Gold, respectively) and net benefit (127,090 BDT.ha ${ }^{-1}$ and 136,090 BDT.ha ${ }^{-1}$ for BRRI dhan29 and Dhani Gold, respectively) were higher in $20 \mathrm{~kg} \cdot \mathrm{N} \cdot \mathrm{ha}^{-1}$ at $\leq 35 \mathrm{SPAD}$ value management approach than control; and moderate among the other treatments. Although maximum $\mathrm{N}$ cost was involved in $30 \mathrm{~kg} \cdot \mathrm{N} \cdot \mathrm{ha}^{-1}$ at $\leq 3.0 \mathrm{LCC}$ value the highest gross income or net benefit was not obtained from this $\mathrm{N}$ management approach, particularly for BRRI dhan29. The highest gross income $\left(146,800 \mathrm{BDT} \cdot \mathrm{ha}^{-1}\right)$ with maximum net benefit $\left(142,120 \mathrm{BDT} \cdot \mathrm{ha}^{-1}\right)$ was found when $20 \mathrm{~kg} \cdot \mathrm{N} \cdot \mathrm{ha}^{-1}$ at $\leq 3.0 \mathrm{LCC}$ value was applied in BRRI dhan29, even though it had moderate $\mathrm{N}$ cost (4680 BDT.ha $\left.{ }^{-1}\right)$ involvement which is still lower than the control $\left(5400 \mathrm{BDT} \cdot \mathrm{ha}^{-1}\right)$. For Dhani gold variety, $30 \mathrm{~kg} \cdot \mathrm{N} \cdot \mathrm{ha}^{-1}$ application at $\leq 35 \mathrm{SPAD}$ value provided considerably higher gross income $\left(139,600 \mathrm{BDT} \cdot \mathrm{ha}^{-1}\right)$ and net income $\left(136,090 \mathrm{BDT} \cdot \mathrm{ha}^{-1}\right)$ over control (which was moderate among the other treatments) with lower (3510 BDT $\cdot \mathrm{ha}^{-1}$ ) $\mathrm{N}$ cost involvement (Table 4) and moderate yield (Table 3). 
Table 4. Economic efficiency of different nitrogen $(\mathrm{N})$ management approaches of winter rice.

\begin{tabular}{|c|c|c|c|c|c|}
\hline \multirow{2}{*}{$\mathrm{N}$ management approaches } & \multirow{2}{*}{$\mathrm{N}$ cost $\left(\mathrm{BDT} \cdot \mathrm{ha}^{-1}\right)$} & \multicolumn{2}{|c|}{ Gross income (BDT $\left.\cdot \mathrm{ha}^{-1}\right)$} & \multicolumn{2}{|c|}{ Net benefit (BDT'ha $\left.{ }^{-1}\right)$} \\
\hline & & BRRI dhan29 & Dhani gold & BRRI dhan29 & Dhani gold \\
\hline BRRI recommended $\mathrm{N}$ (control) & 5400 & 129,800 & 121,000 & 124,400 & 115,600 \\
\hline Soil analysis based $\mathrm{N}$ management & 5634 & 132,600 & 141,600 & 126,966 & 135,966 \\
\hline $\mathrm{N}$ management based on agro-ecological zone & 5868 & 125,800 & 141,000 & 119,932 & 135,135 \\
\hline $20 \mathrm{~kg} \cdot \mathrm{N} \cdot \mathrm{ha}^{-1}$ at $\leq 35 \mathrm{SPAD}$ value & 2340 & 133,000 & 103,800 & 130,660 & 101,460 \\
\hline $30 \mathrm{~kg} \cdot \mathrm{N} \cdot \mathrm{ha}^{-1}$ at $\leq 35 \mathrm{SPAD}$ value & 3510 & 130,600 & 139,600 & 127,090 & 136,090 \\
\hline $20 \mathrm{~kg} \cdot \mathrm{N} \cdot \mathrm{ha}^{-1}$ at $\leq 3.0 \mathrm{LCC}$ value & 4680 & 146,800 & 137,400 & 142,120 & 132,720 \\
\hline $30 \mathrm{~kg} \cdot \mathrm{N} \cdot \mathrm{ha}^{-1}$ at $\leq 3.0 \mathrm{LCC}$ value & 7038 & 134,400 & 145,000 & 127,362 & 137,962 \\
\hline Urea super granule & 3132 & 124,800 & 137,800 & 121,668 & 134,668 \\
\hline
\end{tabular}

$\mathrm{BRRI}=$ Bangladesh rice research institute, $\mathrm{SPAD}=$ Silicon photon activate diode and LCC $=$ Leaf colour chart. Here, Gross income $\left(\mathrm{BDT} \cdot \mathrm{h} \mathrm{a}^{-1}\right)=$ Rice grain yield $\left(\mathrm{kg} \cdot \mathrm{ha}^{-1}\right) \times$ Price $\left(\mathrm{kg}^{-1}\right)$. Net benefit $\left(\right.$ BDT $\left.\cdot \mathrm{ha}^{-1}\right)=$ Gross income $\left(\right.$ BDT $\left.\cdot \mathrm{ha}^{-1}\right)-$ Nitrogen fertilizer cost $\left(\mathrm{BDT} \cdot \mathrm{ha}^{-1}\right)$. Various costs in the experiment: Urea (as nitrogenous fertilizer) $=18 \mathrm{BDT} \cdot \mathrm{Kg}^{-1}$. Rice Grains $=20 \mathrm{BDT} \cdot \mathrm{Kg}^{-1} \cdot 1 \mathrm{US} \$=80 \mathrm{BDT}$ (approx.).

\section{Conclusion}

To conclude, SPAD or LCC based approach for $\mathrm{N}$ management in rice seems more effective than the existing BRRI recommended $\mathrm{N}$ management approach, and the performances of different $\mathrm{N}$ management approaches differ with rice varieties. In winter season, cultivation of BRRI dhan 29 coupled with $20 \mathrm{~kg} \cdot \mathrm{N} \cdot$ application $\cdot \mathrm{ha}^{-1}$

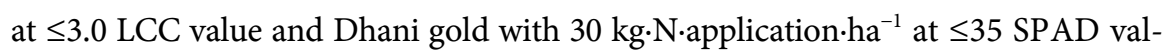
ue can provide maximum grain yield with efficient and cost-effective $\mathrm{N}$ management. However, this conclusion is limited to the specific experimental site, varieties and season. Additional site-specific and multi-year research on this aspect is to be conducted to draw a final conclusion for determining best $\mathrm{N}$ management approach for a specific rice variety to achieve the maximum benefit.

\section{Acknowledgements}

The authors gratefully acknowledge the financial support provided by Bangladesh Agricultural University Research System (BAURES), Bangladesh Agricultural University, Mymensingh-2202 (research project number: 2017/217/AU-GC) to conduct the research work.

\section{Conflicts of Interest}

The authors declare no conflicts of interest regarding the publication of this paper.

\section{References}

[1] BBS (2014) Handbook of Agricultural Statistics. Bangladesh Bureau of Statistics, Ministry of Planning, Government of the People's Republic of Bangladesh, Dhaka, $1-12$.

[2] BBS (2011) Statistical Year Book of Bangladesh. Statistics Division, Ministry of Planning, Bangladesh, Bangladesh Bureau of Statistics, Government of the People's Republic of Bangladesh, Dhaka, 136-140. 
[3] BRRI (2013) Rice in Bangladesh. Bangladesh Rice Research Institute. http://www.knowledgebank-brri.org/riceinban.php

[4] Raun, W.R. and Johnson, G.V. (1999) Improving Nitrogen Use Efficiency for Cereal Production. Agronomy Journal, 91, 357-363. https://doi.org/10.2134/agronj1999.00021962009100030001x

[5] Alam, M.M., Ladha, J.K., Khan, S.R., Khan, A.H. and Buresh, R.J. (2005) Leaf Color Chart for Managing Nitrogen Fertilizer in Lowland Rice in Bangladesh. Agronomy Journal, 97, 949-959. https://doi.org/10.2134/agronj2004.0206

[6] Dash, A.K., Mishra, B.K., Jena, M.K. and Jena, D. (2003) Effect of Dose and Application Methods of Different Urea Based Fertilizers on Yield of Low Land Rice. Annuals of Agricultural Research, 24, 308-313.

[7] Shapiro, C.A., Schepers, J.S., Francis, D.D. and Shanahan, J.F. (2006) Using a Chlorophyll Meter to Improve N Management. University of Nebraska-Lincoln Extension, Lincoln, NE. https://efotg.sc.egov.usda.gov/references/public/MI/Chlorophyll_Meter_N.pdf

[8] Schepers, J.S., Francis, D.D., Vigil, M. and Below, F.E. (1992) Comparison of Corn Leaf Nitrogen Concentration and Chlorophyll Meter Readings. Communications in Soil Science and Plant Analysis, 23, 2173-2187. https://doi.org/10.1080/00103629209368733

[9] Blackmer, T.M. and Schepers, J.S. (1995) Use of a Chlorophyll Meter to Monitor Nitrogen Status and Schedule Fertigation for Corn. Journal of Production Agriculture, 8, 56-60. https://doi.org/10.2134/jpa1995.0056

[10] Balasubramanian, V., Morales, A.C., Cruz, R.T. and Abdulrachman, S. (1998) On-Farm Adaptation of Knowledge-Intensive Nitrogen Management Technologies for Rice Systems. Nutrient Cycling in Agroecosystems, 53, 59-69. https://doi.org/10.1023/A:1009744605920

[11] Witt, C., Pasuquin, J.M.C.A., Mutters, R. and Buresh, R.J. (2005) New Leaf Color Chart for Effective Nitrogen Management in Rice. Better Crops, 89, 36-39.

[12] Gomez, A.K. and Gomez, A.A. (1984) Statistical Procedures for Agricultural Research. 2nd Edition, John Wiley and Sons, New York, 207-215.

[13] Kabir, M.E., Kabir, M.R., Jahan, M.S. and Das, G.G. (2004) Yield Performance of Three Aromatic Fine Rice in a Coastal Medium High Land. Asian Journal of Plant Science, 3, 561-563. https://doi.org/10.3923/ajps.2004.561.563

[14] Rahman, M.M. (2006) Effect of Cultivar, Depth of Transplanting and Depth of Placement of USG on Growth and Yield of Bororice. M.Sc. Thesis, Department of Agronomy, Bangladesh Agricultural University, Mymensingh, 94.

[15] Tayeb, A., Paul, S.K. and Samad, M.A. (2013) Performance of Variety and Spacing on the Yield and Yield Contributing Characters of Transplant Aman rice. Journal of Agroforestry and Environment, 7, 57-60.

[16] Budhar, M.N. (2005) Leaf Colour Chart Based Nitrogen Management in Direct Seeded Rice Puddled Rice (Oryza sativa L). Fertilizer News, 50, 41-44.

[17] Singh, R.D., Sikka, A.K., Shivani and Rajan, K. (2008) Effect of Irrigation and Nitrogen on Yield, Water Use Efficiency and Nutrient Balance in Rice (Oryza sativa) Based Cropping System. The Indian Journal of Agricultural Sciences, 78, 21-26.

[18] Dinesh, D., Baskar, A. and Rajan, K. (2017) Effect of Cultivation Methods and Nitrogen Management Strategies on Growth and Yield of Rice (Oryza sativa L.) Grown in Coastal Alluvial Soils of Southern India. International Journal of Current Microbiology and Applied Sciences, 6, 2176-2187. 
https://doi.org/10.20546/ijcmas.2017.603.248

[19] Islam, M.S., Bhuiya, M.S.U., Rahman, S. and Hussain, M.M. (2009) Evaluation of SPAD and LCC Based Nitrogen Management in (Oryza sativa L.). Bangladesh Journal of Agricultural Research, 34, 661-672.

[20] Islam, M.S., Sarkar, M.A., Uddin, S. and Parvin, S. (2012) Yield of Fine Rice Varieties as Influenced by Integrated Management of Poultry Manure, Urea Super Granules and Prilled Urea. Journal of Environmental Science and Natural Resources, 5 , 129-132. 